\title{
Correction to: Gender pay gap and under-representation of women in decision-making positions: UWE decisions of the European Committee of Social Rights
}

\section{Barbara Kresal $^{1}$}

Published online: 25 May 2021

(c) @ ERA 2021

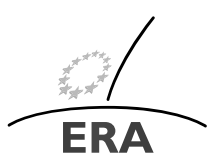

EUROPÄ|SCHE RECHTSAKADEMIE

ACADEMY OF EUROPEAN LAW ACADEMIE DE DROIT EUROPEEN TRIER - TREVES - TREVIRI
TRE

\section{Correction to: ERA Forum https://doi.org/10.1007/s12027-021-00664-8}

When this article was published, a correction by the author to the first footnote had been misinterpreted. Instead of:

${ }^{1}$ The European Social Charter was signed in Turin in 1961 (Council of Europe, ETS No. 035, available at: https://www.coe.int/en/web/conventions/full-list/-/conventions/ treaty/035). In 1988, the Additional Protocol to the ESC was adopted (Council of Europe, ETS No. 128, available at: https://www.coe.int/en/web/conventions/full-list/-/ conventions/treaty/128), adding four new rights to the Charter. In 1996, the Revised European Social Charter was adopted (Council of Europe, ETS No. 163, available at: https://www.coe.int/en/web/conventions/full-list/-/conventions/treaty/163) bringing together in a single treaty all rights enshrined in the 1961 Charter (some of them have been significantly upgraded and updated) and the 1988 Additional Protocol and adding eight new rights. The Charter, in its revised version, now guarantees 31 economic and social human rights, often referred to as fundamental social rights, and was intended to gradually replace the 1961 Charter. However, eight countries are still bound by the 1961 Charter, while 35 countries have already ratified and are bound by the 1996 Revised Charter, and on 29 March 2021, Germany ratified it. In 2020, German Bundestag approved the Government's proposal to ratify the revised Charter.

The original article can be found online at https://doi.org/10.1007/s12027-021-00664-8

B. Kresal

barbara.kresal@fsd.uni-lj.si

1 Associate Professor of Labour Law and Social Security, University of Ljubljana, Ljubljana,

Slovenia 
Ratifications and accepted provisions by the States Parties available at: https://www. coe.int/en/web/european-social-charter/home.

The footnote should have read

${ }^{1}$ The European Social Charter was signed in Turin in 1961 (Council of Europe, ETS No. 035, available at: https://www.coe.int/en/web/conventions/full-list/-/conventions/ treaty/035). In 1988, the Additional Protocol to the ESC was adopted (Council of Europe, ETS No. 128, available at: https://www.coe.int/en/web/conventions/full-list/-/ conventions/treaty/128), adding four new rights to the Charter. In 1996, the Revised European Social Charter was adopted (Council of Europe, ETS No. 163, available at: https://www.coe.int/en/web/conventions/full-list/-/conventions/treaty/163) bringing together in a single treaty all rights enshrined in the 1961 Charter (some of them have been significantly upgraded and updated) and the 1988 Additional Protocol and adding eight new rights. The Charter, in its revised version, now guarantees 31 economic and social human rights, often referred to as fundamental social rights, and was intended to gradually replace the 1961 Charter. However, eight countries are still bound by the 1961 Charter, while 35 countries have already ratified and are bound by the 1996 Revised Charter. In 2020, German Bundestag approved the Government's proposal to ratify the revised Charter, and on 29 March 2021, Germany ratified it. Ratifications and accepted provisions by the States Parties available at: https://www. coe.int/en/web/european-social-charter/home.

The original article has been corrected.

The publisher apologises for this mistake.

Publisher's Note Springer Nature remains neutral with regard to jurisdictional claims in published maps and institutional affiliations. 